\title{
Adenosine Triphosphate Citrate Lyase Mediates Hypocitraturia in Rats
}

\author{
Joel Z. Melnick, ${ }^{\star \ddagger}$ Paul A. Srere, ${ }^{\S \|}$ Nabil A. Elshourbagy, \\ $*$ Department of Internal Medicine, ${ }^{\ddagger}$ Department of Pediatrics, and ${ }^{\S}$ Department of Biochemistry, University of Texas Southwestern \\ Medical Center, Dallas, Texas 75235; "VAMC, Dallas, Texas; and ${ }^{\mathbb{I}}$ SmithKline Beecham, King of Prussia, Pennsylvania 19406
}

\begin{abstract}
Chronic metabolic acidosis increases proximal tubular citrate uptake and metabolism. The present study addressed the effect of chronic metabolic acidosis on a cytosolic enzyme of citrate metabolism, ATP citrate lyase. Chronic metabolic acidosis caused hypocitraturia in rats and increased renal cortical ATP citrate lyase activity by $67 \%$ after $7 \mathrm{~d}$. Renal cortical ATP citrate lyase protein abundance increased by $29 \%$ after $3 \mathrm{~d}$ and by $141 \%$ after $7 \mathrm{~d}$ of acid diet. No significant change in mRNA abundance could be detected. Hypokalemia, which causes only intracellular acidosis, caused hypocitraturia and increased renal cortical ATP citrate lyase activity by $28 \%$. Conversely, the hypercitraturia of chronic alkali feeding was associated with no change in ATP citrate lyase activity. Inhibition of ATP citrate lyase with the competitive inhibitor, $4 \mathrm{~S}$-hydroxycitrate, significantly abated hypocitraturia and increased urinary citrate excretion fourfold in chronic metabolic acidosis and threefold in $\mathrm{K}^{+}$-depletion. In summary, the hypocitraturia of chronic metabolic acidosis is associated with an increase in ATP citrate lyase activity and protein abundance, and is partly reversed by inhibition of this enzyme. These results suggest an important role for ATP citrate lyase in proximal tubular citrate metabolism. (J. Clin. Invest. 1996. 98:23812387.) Key words: urolithiasis • acidosis • citrate • hydroxycitrate $\cdot$ hypokalemia
\end{abstract}

\section{Introduction}

Urinary citrate plays an important role in preventing formation of calcium-containing kidney stones by chelating calcium, directly inhibiting the crystallization and precipitation of calcium, and interacting with Tamm-Horsfal proteins to inhibit Ca-oxalate crystallization $(1,2)$. Low urinary citrate occurs in approximately half of patients with renal stone disease (3). In many patients, this hypocitraturia can be ascribed to some form of metabolic acidosis $(4,5)$, excess acid generation $(6,7)$, or hypokalemia (decreased intracellular $\left.\mathrm{pH}, \mathrm{pH}_{\mathrm{i}}^{1}\right)(8,9)$.

Citrate is freely filtered by the glomerulus and reabsorbed in the proximal tubule (10). Because the filtered load of citrate

Address correspondence to Joel Z. Melnick, Northwestern University Medical School, Pediatrics W-140, 303 E. Chicago Ave., Chicago, IL 60611. Phone: 312-880-4326; FAX: 312-880-6776.

Received for publication 27 February 1996 and accepted in revised form 12 September 1996.

1. Abbreviation used in this paper: $\mathrm{pH}_{\mathrm{i}}$, intracellular $\mathrm{pH}$.

J. Clin. Invest.

(C) The American Society for Clinical Investigation, Inc.

0021-9738/96/11/2381/07 \$2.00

Volume 98, Number 10, November 1996, 2381-2387 remains relatively constant, the rate of proximal tubular citrate reabsorption is the major determinant of urinary citrate excretion. The renal proximal tubule reabsorbs citrate through an apical membrane $\mathrm{Na}$ /citrate cotransporter $(11,12)$. Once absorbed across the apical membrane, it is believed that cytosolic citrate is transported into mitochondria and metabolized in the tricarboxylic acid cycle (13). However, in other tissues, an alternate pathway for citrate metabolism occurs in the cytoplasm through ATP citrate lyase, which cleaves citrate to oxaloacetate and acetyl CoA (14).

The purpose of the present study was to determine the role of ATP citrate lyase in renal citrate metabolism. The results demonstrate that the hypocitraturia of chronic metabolic acidosis and hypokalemia is associated with adaptive increases in ATP citrate lyase activity. In addition, inhibiting ATP citrate lyase with 4S-hydroxycitrate (15) attenuates the hypocitraturia of chronic metabolic acidosis and hypokalemia, demonstrating a role for this enzyme in mediating hypocitraturia.

\section{Methods}

\section{Experimental design}

Male Sprague-Dawley rats (180-200 g; Harlan Sprague-Dawley Inc., Indianapolis, IN) were treated with the following protocols.

Chronic acid feeding. The basic diet consisted of ground $4 \%$-fat rat/mouse chow (Teklad Premier Laboratory Diets, Madison, WI). Animals were fed ad lib for $2 \mathrm{~d}$ to allow them to acclimate to the metabolic cages. After $2 \mathrm{~d}$, control rats were pair fed to rats receiving the same diet, but with $0.28 \mathrm{M} \mathrm{NH}_{4} \mathrm{Cl}$ in their drinking water.

Chronic alkali feeding. The animals were placed in metabolic cages and allowed to acclimate on a synthetic diet consisting of (in $\mathrm{g} / \mathrm{kg}$ ) 180 casein, 200 cornstarch, 500 sucrose, 35 corn oil, 35 peanut oil, 10 $\mathrm{CaHPO}_{4}, 6 \mathrm{MgSO}_{4}, 6 \mathrm{NaCl}, 8.3 \mathrm{~K}_{2} \mathrm{HPO}_{4}$, and 10-vitamin fortification mixture (ICN Nutritional Biochemicals, Cleveland, $\mathrm{OH}$ ) for $2 \mathrm{~d}$. Subsequently, control rats receiving the synthetic diet plus $6 \mathrm{mmol} / \mathrm{kg}$ body wt per $\mathrm{d} \mathrm{NaCl}$ were pair fed to rats receiving the synthetic diet plus $6 \mathrm{mmol} / \mathrm{kg}$ body wt per day $\mathrm{NaHCO}_{3}$.

Chronic $\mathrm{K}^{+}$-deficiency. The animals were placed in metabolic cages and allowed to acclimate on a synthetic diet consisting of (in g/kg) 180 casein, 200 cornstarch, 500 sucrose, 35 corn oil, 35 peanut oil, 10 $\mathrm{CaHPO}_{4}, 6 \mathrm{MgSO}_{4}, 6.8 \mathrm{Na}_{2} \mathrm{HPO}_{4}, 7.1 \mathrm{KCl}$, and 10-vitamin fortification mixture. After $2 \mathrm{~d}$, control rats continued on this diet and were pair fed to rats receiving the same diet with $\mathrm{NaCl}$ substituted for $\mathrm{KCl}$.

For the above groups, 24-h urine collections were obtained on day 7 in the presence of thymol to prevent bacterial digestion of citrate (16). On day 8, the animals were anesthetized with $100 \mathrm{mg} / \mathrm{kg}$ body wt Inactin (Promonta, Germany) by intraperitoneal injection. Arterial blood gases were obtained by aortic puncture through an abdominal incision. Kidneys then were harvested immediately, the outer capsule removed, and the kidney placed in ice cold PBS.

In vivo inhibition of ATP citrate lyase. 4S-hydroxycitrate inhibits the function of ATP citrate lyase in vivo (17). After $7 \mathrm{~d}$ of control, acid, or $\mathrm{K}^{+}$-free diet, rats received either $2 \mathrm{mmol} / \mathrm{kg}$ body wt per day i.p. of $4 \mathrm{~S}$-hydroxycitrate (kindly provided by Hoffman-LaRoche, Nutley, NJ; neutralized with $\mathrm{NaOH}$ to $\mathrm{pH}$ 7.4) or an equal volume and concentration of saline. The injections were given at $0800 \mathrm{~h}$ for an 
additional $2 \mathrm{~d}$ of dietary protocol. During the second additional day, a 24-h urine sample was collected. Rats then were anesthetized and aortic blood was collected and analyzed.

Blood gas determinations were performed using a CMS System 1304 blood gas analyzer (Instrumentation Laboratory, Inc., Lexington, MA); electrolytes and creatinine were measured on an Astra 7 electrolyte analyzer (Beckman Instruments Inc., Fullerton, CA). Citrate measurements were performed using a citric acid enzymatic kit (Boehringer Mannheim Biochemicals, Indianapolis, IN) on the Cobas Fara II chemistry system (Roche Diagnostic Systems, Somerville, $\mathrm{NJ}$ ).

\section{Measurement of renal cortical apical membrane $\mathrm{Na}$ /citrate cotransporter}

Kidneys were placed in ice cold PBS. The renal cortex was dissected away and minced on an iced petri dish. Cortical tissue was placed in $15 \mathrm{ml}$ of buffer (300 mM mannitol, $16 \mathrm{mM}$ Hepes/20 mM Tris, $\mathrm{pH} 7.4$, $5 \mathrm{mM}$ EGTA, and $100 \mu \mathrm{g} / \mathrm{ml}$ PMSF) and homogenized with a Polytron (Brinkman Instruments, Inc., Westbury, NY). Brush border membrane vesicles were isolated by $\mathrm{Mg}^{2+}$ precipitation and differential centrifugation as previously described (18). The final pellet was resuspended in $15 \mathrm{ml}$ of intravesicular buffer consisting of (in $\mathrm{mM}$ )

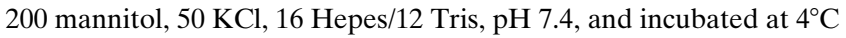
for $1 \mathrm{~h}$. Membranes were pelleted and resuspended in $0.5 \mathrm{ml}$ of intravesicular buffer for transport studies.

Na-dependent citrate transport was determined in brush border membrane vesicles as previously described (18) using the difference between $1,5-{ }^{14} \mathrm{C}$-citrate (New England Nuclear, Boston, MA) uptake in Na-free (consisting of [in $\mathrm{mM}$ ] 100 choline $\mathrm{Cl}, 50 \mathrm{KCl}, 16 \mathrm{Hepes} / 12$ Tris, $\mathrm{pH}$ 7.4) and Na-containing ([in $\mathrm{mM}] 100 \mathrm{NaCl}, 50 \mathrm{KCl}, 16$ Hepes/12 Tris, $\mathrm{pH}$ 7.4) extravesicular solutions. Increasing concentrations of $4 \mathrm{~S}$-hydroxycitrate, from $10^{-7}$ to $10^{-2} \mathrm{M}$, were added to the extravesicular fluids. We measured uptake over $10 \mathrm{~s}$ at room temperature using the Millipore filtration technique with $0.65-\mu \mathrm{m}$ pore size cellulose nitrate filters (DAWP 2500; Millipore Corp., Bedford, MA).

\section{Measurement of ATP citrate lyase activity}

$1 \mathrm{~g}$ renal cortical tissue was homogenized in $10 \mathrm{ml}$ ice cold homogenization solution ( $300 \mathrm{mM}$ sucrose, $5 \mathrm{mM} \mathrm{KH}_{2} \mathrm{PO}_{4}, 1 \mathrm{mM}$ EGTA, $0.1 \%$ BSA, $10 \mathrm{mM} \mathrm{Na}_{3}$ citrate, $5 \mathrm{mM}$ Mops, $\mathrm{pH} 7.4,50 \mu \mathrm{g} / \mathrm{ml}$ PMSF, and 4 $\mu \mathrm{g} / \mathrm{ml}$ aprotinin) with 4 strokes of a Potter-Elvehjem. The homogenate was centrifuged at $48,000 \mathrm{~g}$ for $20 \mathrm{~min}$ at $4^{\circ} \mathrm{C}$. The supernatant was placed at $-20^{\circ} \mathrm{C}$ overnight in the presence of $6.5 \mathrm{mM}$ dithiothreitol to reduce the sulfhydryl groups of the enzyme (19).

ATP citrate lyase activity was measured using the hydroxamate assay (20). Attempts to use the malate dehydrogenase coupled assay (21) were unsuccessful because of high native renal NADH dehydrogenase activity. The assay solution contained (in $\mathrm{mM}$ ) $20 \mathrm{Na}_{3}$ cit- rate, $10 \mathrm{MgCl}_{2}, 200$ hydroxylamine, and 20 Tris- $\mathrm{HCl}, \mathrm{pH}$ 8.4. Coenzyme A-dependent acetylation was determined by performing the assay with and without $0.1 \mathrm{mM} \mathrm{CoA} .100 \mu \mathrm{g}$ of cytosolic protein was added to the assay solution in a total volume of $475 \mu$. The reaction was started by adding $25 \mu \mathrm{l}$ of $0.1 \mathrm{M}$ ATP and allowed to continue for $30 \mathrm{~min}$ at $37^{\circ} \mathrm{C} .1 \mathrm{ml}$ of $12.5 \%$ trichloroacetic acid was added to stop the reaction. The amount of acetylhydroxamate generated was quantitated spectrophotometrically at $520 \mathrm{~nm}$ in the presence of $\mathrm{FeCl}_{3}$ ( $0.2 \mathrm{M}$ final concentration). The difference in absorbance between the reaction performed in the presence and absence of CoA determined the ATP citrate lyase specific generation of acetylhydroxamate.

\section{Immunoblotting}

Cortex was placed in TBS $(150 \mathrm{mM} \mathrm{NaCl} / 20 \mathrm{mM}$ Tris- $\mathrm{HCl}, \mathrm{pH} 7.4)$ containing protease inhibitors ( $100 \mu \mathrm{g} / \mathrm{ml}$ PMSF, $2 \mu \mathrm{g} / \mathrm{ml}$ aprotinin, 2 $\mu \mathrm{g} / \mathrm{ml}$ leupeptin, $2 \mu \mathrm{g} / \mathrm{ml}$ pepstatin A, and $2 \mathrm{mM}$ EDTA), and homogenized for four strokes of a Potter-Elvehjem. The homogenate was centrifuged at $10,000 \mathrm{~g}$ for $30 \mathrm{~min}$ at $4^{\circ} \mathrm{C}$. The supernatant was size fractionated by SDS/PAGE on a $6 \%$ gel and electrophoretically transferred to nitrocellulose membranes. After blocking with $5 \%$ powdered milk and $0.1 \%$ Tween 20 in TBS for $1 \mathrm{~h}$, blots were probed with a 1:300 dilution of a rabbit anti-rat ATP citrate lyase antibody (22) for $1 \mathrm{~h}$, and washed three times with TBS containing $5 \%$ powdered milk and $0.5 \%$ Tween 20 , and then once in PBS. Blots then were incubated in TBS with $0.5 \%$ Tween 20 and a 1:5,000 dilution of horseradish peroxidase-labeled anti-rabbit IgG and washed three times with TBS containing $0.5 \%$ Tween 20 , and then once in PBS. Binding was detected by enhanced chemiluminescence (Amersham International, Little Chalfont, UK) and quantitated by densitometry.

\section{Northern blotting}

Renal cortical tissue was placed in a guanidium thiocyanate solution containing $4 \mathrm{M}$ guanidium thiocyanate (Fisher Scientific Co., Fair Lawn, NJ), $0.75 \mathrm{M}$ sodium citrate, $17 \mathrm{mM} \mathrm{N}$-lauroyl-sarcosine, $0.1 \mathrm{M}$ $\beta$-mercaptoethanol, and homogenized using a Polytron. Total RNA was isolated by acid phenol extraction, size fractionated by formaldehyde gel electrophoresis, and transferred to nylon membranes. Probing was performed as previously described (23) using a randomprimed uniformly ${ }^{32} \mathrm{P}$-labeled full length ATP citrate lyase cDNA (22). 18S cDNA (American Type Culture Collection, Rockville, MD) was used in sequential probing to control for loading. Densitometry was performed and results were normalized for $18 \mathrm{~S}$ mRNA abundance.

Sigma Chemical Co. (St. Louis, MO) supplied all chemicals unless otherwise noted. All protein concentrations were determined using the bicinchoninic acid assay method (Pierce Chemical Co., Rockford, IL). Data are expressed as mean \pm SEM. All comparisons were made using the paired $t$ test (Sigma Stat; Jandel Science, San Rafael, CA).

Table I. Plasma Values for Control and Experimental Groups on Respective Diets

\begin{tabular}{|c|c|c|c|c|c|c|}
\hline & \multicolumn{2}{|c|}{ Acid feeding } & \multicolumn{2}{|c|}{ Alkali feeding } & \multicolumn{2}{|c|}{$\mathrm{K}^{+}$-deficiency } \\
\hline & Control & Experimental & Control & Experimental & Control & Experimental \\
\hline $\mathrm{pH}$ & $7.41 \pm 0.02$ & $7.35 \pm 0.02$ & $7.42 \pm 0.02$ & $7.41 \pm 0.01$ & $7.41 \pm 0.01$ & $7.37 \pm 0.01 *$ \\
\hline $\mathrm{pCO}_{2}(\mathrm{mmHg})$ & $38.9 \pm 1.1$ & $39.0 \pm 1.1$ & $39.1 \pm 1.3$ & $39.3 \pm 1.1$ & $40 \pm 2$ & $43 \pm 2 *$ \\
\hline $\mathrm{HCO}_{3}$ (meq/liter) & $24.4 \pm 0.4$ & $21.6 \pm 0.7 *$ & $25.6 \pm 0.3$ & $25.4 \pm 0.7$ & $25.4 \pm 0.4$ & $25.4 \pm 0.3$ \\
\hline $\mathrm{Na}$ (meq/liter) & $142 \pm 1$ & $145 \pm 2$ & $140 \pm 1$ & $140 \pm 1$ & $142 \pm 1$ & $143 \pm 1$ \\
\hline K (meq/liter) & $3.9 \pm 0.1$ & $3.8 \pm 0.3$ & $4.0 \pm 0.1$ & $3.9 \pm 0.1$ & $3.6 \pm 0.1$ & $2.5 \pm 0.01 *$ \\
\hline $\mathrm{Cl}$ (meq/liter) & $106 \pm 1$ & $110 \pm 1 *$ & $110 \pm 1$ & $109 \pm 1$ & $107 \pm 1$ & $107 \pm 1$ \\
\hline Creatinine $(\mathrm{mg} / \mathrm{dl})$ & $0.4 \pm 0.03$ & $0.4 \pm 0.02$ & $0.4 \pm 0.02$ & $0.4 \pm 0.02$ & $0.4 \pm 0.02$ & $0.5 \pm 0.03^{*}$ \\
\hline Glucose $(\mathrm{mg} / \mathrm{dl})$ & $165 \pm 5$ & $159 \pm 5$ & $198 \pm 3$ & $202 \pm 3$ & $187 \pm 5$ & $174 \pm 8 *$ \\
\hline Citrate (mg/liter) & $68 \pm 3$ & $50 \pm 4 *$ & $41 \pm 3$ & $38 \pm 1$ & $36 \pm 2$ & $40 \pm 2$ \\
\hline
\end{tabular}

$n=6$ for acid and alkali groups, $n=7$ for $\mathrm{K}^{+}$-deficient group. $* P<0.05$ vs. control. 


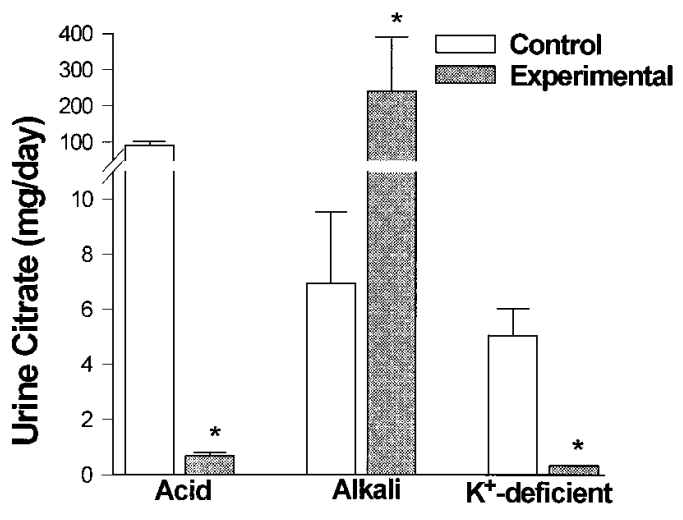

Figure 1. Urinary citrate excretion. Absolute urine citrate excretion during day 7 of either acid, alkali, or $\mathrm{K}^{+}$-deficient diet protocols. $* P<0.05$ vs. control.

\section{Results}

Chronic metabolic acidosis increases renal cortical ATP citrate lyase activity. We reasoned that if ATP citrate lyase plays an important role in proximal tubular citrate metabolism, chronic metabolic acidosis may cause a chronic adaptation in its activity. To examine this, rats were pair fed either control or acid diets for $7 \mathrm{~d}$. Control and experimental animals gained a simi-

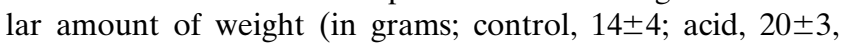
NS). As shown in Table I, acidotic animals developed a small but significant metabolic acidosis as evidenced by a decrease in their plasma $\left(\mathrm{HCO}_{3}{ }^{-}\right)$and blood $\mathrm{pH}$, and increase in plasma $\left(\mathrm{Cl}^{-}\right)$. The absence of a compensatory respiratory alkalosis in the acidotic animals may have been due to the fact that blood gases were measured immediately after administration of anesthesia. Acid feeding also caused a significant decrease in

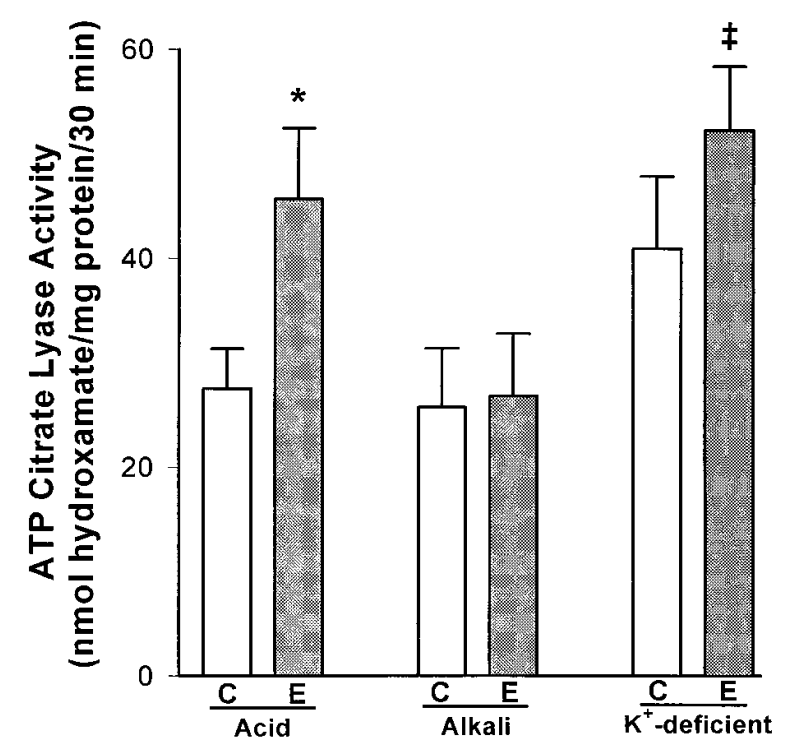

Figure 2. Chronic metabolic acidosis or $\mathrm{K}^{+}$-deficiency increases ATP citrate lyase activity. Alkali feeding did not affect enzyme activity. ATP citrate lyase activity was determined as the generation of acetylhydroxamate in animals receiving either control $(C)$ or experimental (E) diets for $7 \mathrm{~d}$ on chronic acid, alkali, or $\mathrm{K}^{+}$-deficent protocols, $n=$ 6. $* P<0.01$ and ${ }^{\ddagger} P<0.05$ vs. control. plasma [citrate]. Although the magnitude of the metabolic acidosis was small, acid feeding caused a large decrease in absolute urinary citrate excretion (Fig. 1). As shown in Fig. 2, renal cortical ATP citrate lyase activity was increased by $67 \%$ in acid-fed rats.

Since the abundance of ATP citrate lyase is highest in liver (24), we examined whether acid feeding caused an adaptation in hepatic ATP citrate lyase activity. Liver homogenates were prepared and the assay was performed as in kidney cortex. While ATP citrate lyase activity was 50-fold higher in liver compared with kidney cortex, chronic metabolic acidosis did not affect enzyme activity (in micromoles acetylhydroxamate/ milligram protein per $30 \mathrm{~min}$; control, $1.30 \pm 0.07$; acid, $1.22 \pm$ $0.07, n=6)$.

To determine if alkali feeding had an opposite effect on renal cortical ATP citrate lyase activity, rats were administered $\mathrm{NaHCO}_{3}$ for $7 \mathrm{~d}$. Alkali-fed rats gained a similar amount of

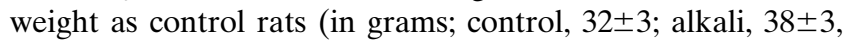
NS) and, as shown in Table I, displayed no change in plasma composition. This is likely due to the kidneys' ability to correct metabolic alkalosis. Nevertheless, these animals did demonstrate an increase in absolute urinary citrate excretion (Fig. 1). In spite of the development of hypercitraturia, these animals demonstrated no change in renal cortical ATP citrate lyase activity (Fig. 2). This observation is analogous to that found with the apical membrane $\mathrm{Na}$ /citrate cotransporter, where chronic acid feeding caused an increase in transporter activity, but chronic alkali feeding had no effect (25).

Chronic metabolic acidosis increases renal cortical ATP citrate lyase protein abundance. To determine if changes in ATP citrate lyase protein abundance could explain the effect of acid feeding on ATP citrate lyase activity, we performed immunoblotting. As shown in Fig. 3 (lanes 4 and 5), rabbit anti-rat ATP citrate lyase antibodies labeled a number of bands in kidney and liver homogenates in addition to the predicted $120-\mathrm{kD}$ band (arrow, Fig. 3) (26). Three findings in Fig. 3 support the specificity of the $120-\mathrm{kD}$ band. First, it is the only band labeled in both kidney and liver homogenates (lanes 4 and 5). Second, purified ATP citrate lyase protein ran at $120 \mathrm{kD}$ (lane 6). Third, preincubation of the antibody with excess purified rat liver ATP citrate lyase protein prevented labeling of the pure enzyme, and the $120-\mathrm{kD}$ band in liver and kidney (lanes 1-3).

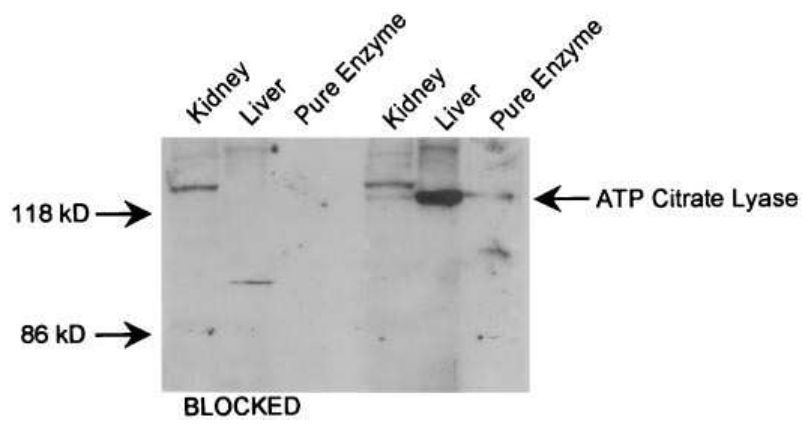

Figure 3. Specificity of anti-ATP citrate lyase antibody. Immunoblot with anti-ATP citrate lyase antibody (1:300 dilution) performed in the presence and absence of blocking with excess purified ATP citrate lyase $(10 \mu \mathrm{g})$. Lanes were loaded with $50 \mu \mathrm{g}$ renal cortical protein, $10 \mu \mathrm{g}$ liver protein, or $0.5 \mu \mathrm{g}$ purified rat liver ATP citrate lyase protein as indicated. The antibody labeled a $120-\mathrm{kD}$ band in all three lanes, which was blocked by preincubation of antibody with antigen. 

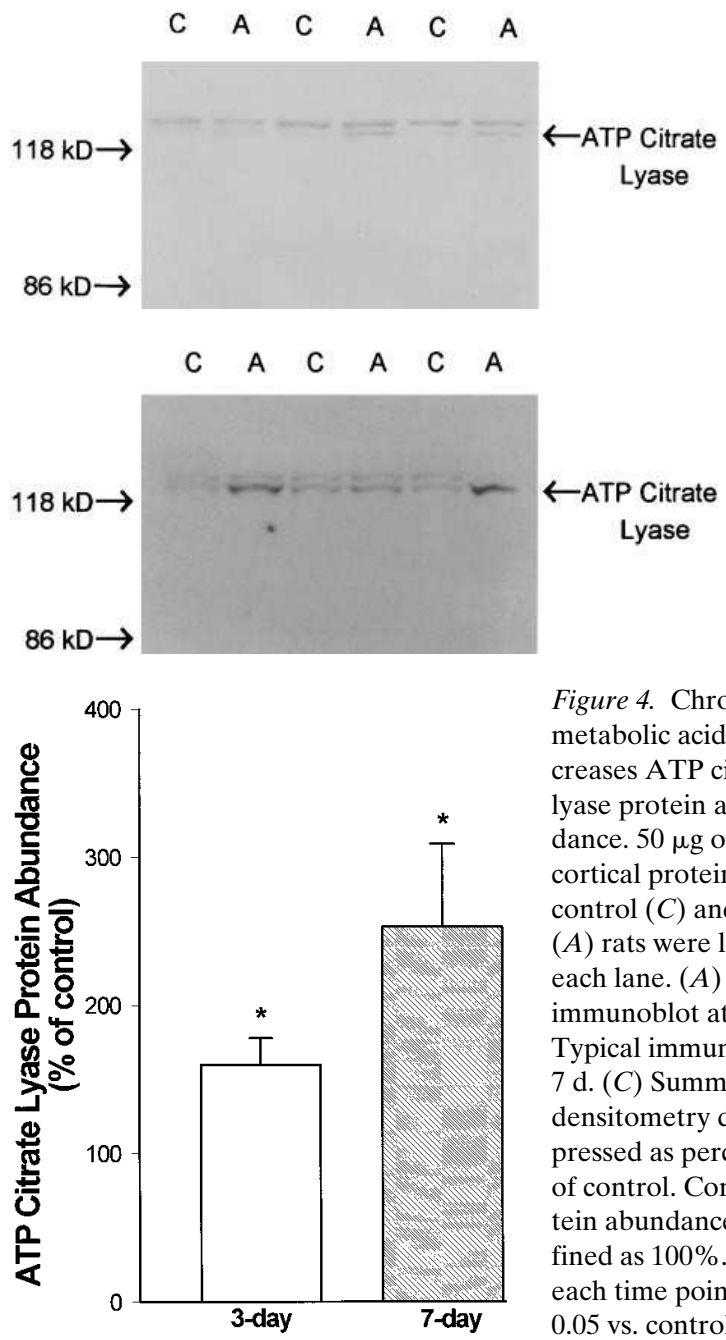

Figure 4. Chronic metabolic acidosis increases ATP citrate lyase protein abundance. $50 \mu \mathrm{g}$ of renal cortical protein from control $(C)$ and acid $(A)$ rats were loaded in each lane. $(A)$ Typical immunoblot at $3 \mathrm{~d}$. (B) Typical immunoblot at 7 d. (C) Summary of densitometry data expressed as percentage of control. Control protein abundance is defined as $100 \% . n=6$ at each time point. $* P<$ 0.05 vs. control.

Immunoblotting of renal cortex demonstrated an increase in ATP citrate lyase protein abundance by $29 \%$ after $3 \mathrm{~d}$ of acid and by $141 \%$ after $7 \mathrm{~d}(n=6$ at each time point, $P<0.05$ for both, Fig. 4).

To examine whether the increase in ATP citrate lyase pro- tein abundance was accompanied by a change in mRNA abundance, RNA blotting was performed on renal cortical RNA. The ATP citrate lyase probe labeled an appropriately sized band of $4.4 \mathrm{~kb}$ in total RNA. Representative blots are shown in Fig. 5. After 3 d, acid feeding caused an increase in mRNA abundance in four of six animals with a mean increase of $23 \%$ for the group. After $7 \mathrm{~d}$, acid feeding was associated with an increase in mRNA abundance in three of six animals for a mean increase of $5 \%$. Neither time point reached statistical significance.

Chronic $\mathrm{K}^{+}$-deficiency increases ATP citrate lyase activity. Hypocitraturia is also observed in chronic $\mathrm{K}^{+}$-deficiency $(8$, $27)$. Because chronic $\mathrm{K}^{+}$-deficiency is associated with extracellular alkalosis and intracellular acidosis (9), it has been inferred that $\mathrm{pH}_{\mathrm{i}}$ is the key regulator of proximal tubular citrate reabsorption (28). To address whether intra- or extracellular $\mathrm{pH}$ is the key regulator of ATP citrate lyase activity, we examined the effect of chronic $\mathrm{K}^{+}$-deficiency on ATP citrate lyase activity. Rats fed a control diet were compared with rats pair fed a $\mathrm{K}^{+}$-free diet for $7 \mathrm{~d}$. A high sodium, $\mathrm{K}^{+}$-free diet was used to prevent the development of metabolic alkalosis (29). As shown in Table I, rats fed a $\mathrm{K}^{+}$-free diet developed hypokalemia. There was no change in plasma bicarbonate concentration. The $\mathrm{K}^{+}$-deficient animals demonstrated a decrease in absolute urinary citrate excretion (Fig. 1). As shown in Fig. $2, \mathrm{~K}^{+}$-deficient animals displayed a $28 \%$ increase in renal cortical ATP citrate lyase activity. Thus, these studies suggest that intracellular, rather than extracellular, acidosis is responsible for the increase in ATP citrate lyase activity.

Inhibition of ATP citrate lyase attenuates hypocitraturia of chronic metabolic acidosis and $K^{+}$-depletion. The above studies demonstrate that acidosis and $\mathrm{K}^{+}$-deficiency increase ATP citrate lyase activity, but do not address whether this adaptation contributes to the hypocitraturia in these conditions. To address this, we examined the effect of the competitive inhibitor of ATP citrate lyase, 4S-hydroxycitrate, on urinary citrate excretion in rats on control, acid, and $\mathrm{K}^{+}$-free diets. 4S-hydroxycitrate has been shown to inhibit ATP citrate lyase selectively without affecting citrate synthase, isocitrate dehydrogenase, aconitase, or the mitochondrial citrate/malate exchanger (30). However, it is not known whether this inhibitor affects the $\mathrm{Na}$ / citrate cotransporter in the renal proximal tubular apical mem-
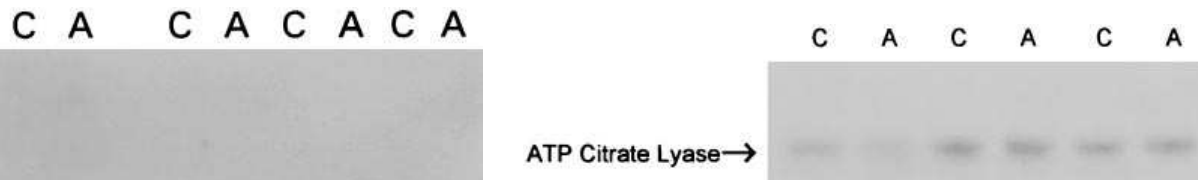

\section{ATP Citrate Lyase $\longrightarrow$}
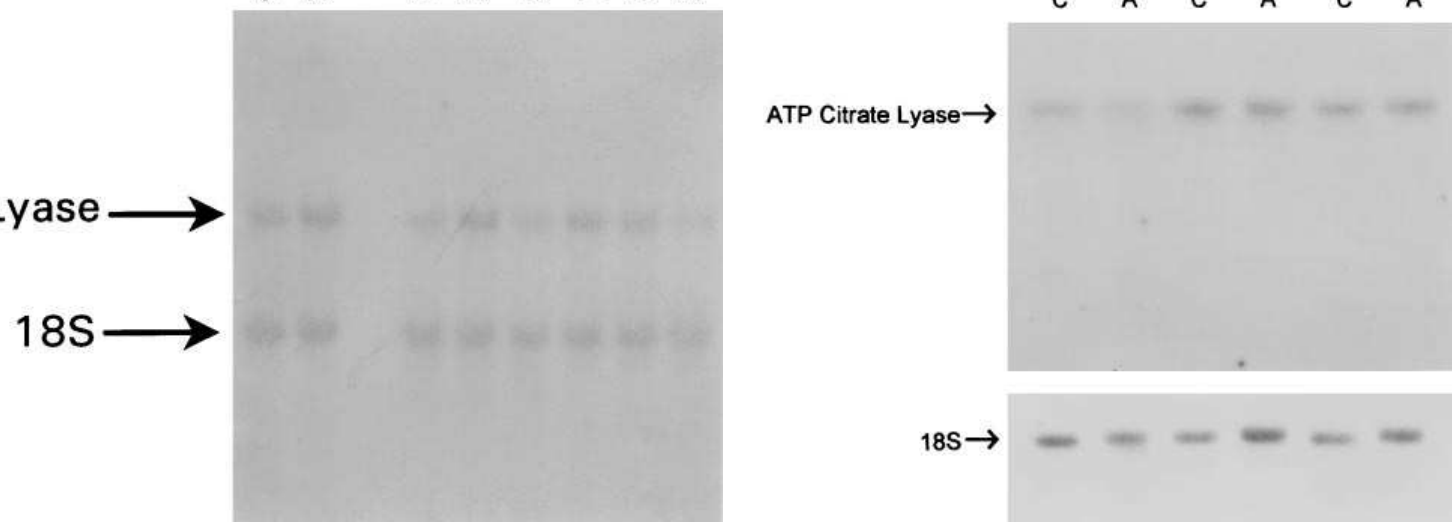

Figure 5. Chronic metabolic acidosis does not affect ATP citrate lyase mRNA abundance. $10 \mu \mathrm{g}$ of renal cortical total RNA from control $(C)$ and acid $(A)$ rats were loaded in each lane. $(A)$ Typical RNA blot at $3 \mathrm{~d}$. $(B)$ Typical RNA blot at $7 \mathrm{~d}$. Blots were probed for ATP citrate lyase and $18 \mathrm{~S}$. 


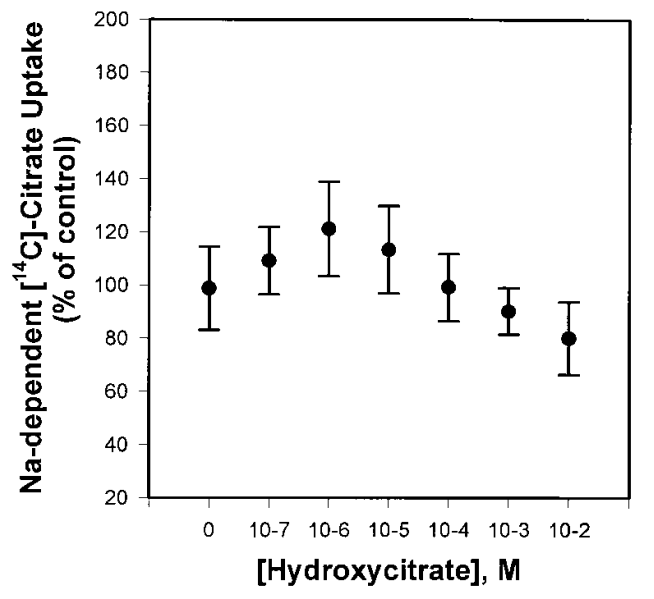

Figure 6. 4S-hydroxycitrate does not inhibit the proximal tubular apical membrane $\mathrm{Na}$ /citrate cotransporter. $\mathrm{Na}$-dependent ${ }^{14} \mathrm{C}$-citrate uptake measured in the presence of increasing concentrations of the ATP citrate lyase inhibitor, 4S-hydroxycitrate, is plotted. Uptake is expressed as percentage of control (in the absence of 4S-hydroxycitrate).

brane. Fig. 6 shows that at concentrations from $10^{-7}$ to $10^{-2} \mathrm{M}$, 4S-hydroxycitrate has no effect on $\mathrm{Na}$-dependent citrate uptake in renal cortical brush border membrane vesicles when compared with control studies performed in the absence of inhibitor.

Rats were fed control, acid, or $\mathrm{K}^{+}$-free diets for $9 \mathrm{~d}$, and on the last $2 \mathrm{~d}$ received $2 \mathrm{mmol} / \mathrm{kg}$ per d $4 \mathrm{~S}$-hydroxycitrate $(\mathrm{OH}$ citrate) or vehicle. Plasma values are shown in Table II. 4Shydroxycitrate caused no significant changes in plasma composition. As shown in Fig. 7, acid feeding and $\mathrm{K}^{+}$-depletion caused hypocitraturia. 4S-hydroxycitrate had a small, insignificant effect on urinary citrate excretion in control rats. In both acid-fed and $\mathrm{K}^{+}$-depleted rats, 4S-hydroxycitrate significantly increased absolute citrate excretion four- and threefold, respectively. Thus, 4S-hydroxycitrate partially inhibits hypocitraturia induced by metabolic acidosis or $\mathrm{K}^{+}$-depletion.

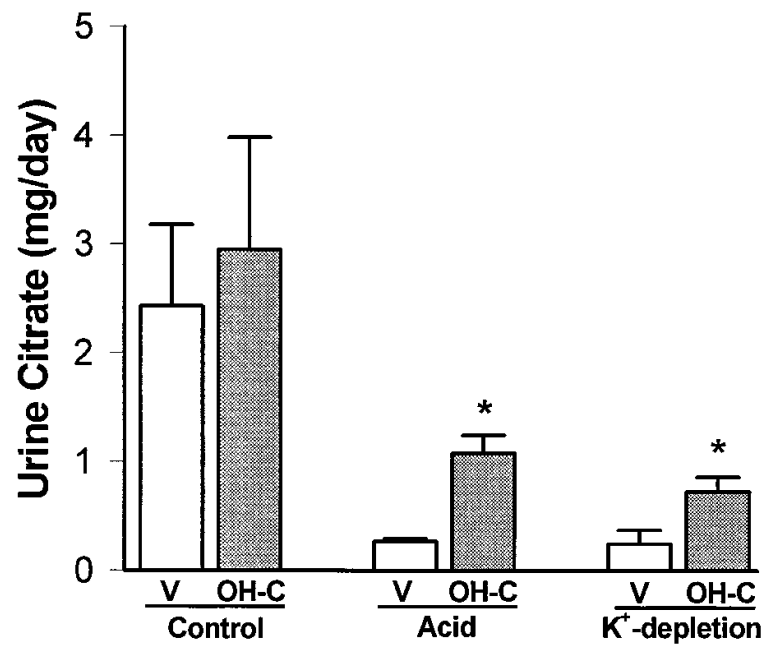

Figure 7. 4S-hydroxycitrate inhibits acidosis- and $\mathrm{K}^{+}$-depletioninduced hypocitraturia. Rats ingested either control, acid, or $\mathrm{K}^{+}$-free diets for $9 \mathrm{~d}$, and received either vehicle $(V)$ or $2 \mathrm{mmol} / \mathrm{kg}$ per $\mathrm{d}$ of $4 \mathrm{~S}$ hydroxycitrate $(\mathrm{OH}-\mathrm{C})$ on the last $2 \mathrm{~d}$. 24-h urine samples were collected during day 2 of either vehicle or hydroxycitrate, $n=6$ for control and acid, $n=4$ for $\mathrm{K}^{+}$-depletion. $* P<0.05$ vs. vehicle.

\section{Discussion}

The proximal tubule serves as the principal site of renal tubular citrate reabsorption and provides the major site for the regulation of renal citrate absorption and excretion (10). The first step in proximal tubular citrate absorption is citrate transport across the apical membrane on the $\mathrm{Na}$ /citrate cotransporter. This transporter is acutely stimulated by decreases in luminal $\mathrm{pH}$, which modulate the relative concentrations of citrate $^{-2}$ (the transported substrate) and citrate $^{-3}$ (31). In addition, chronic acidosis and $\mathrm{K}^{+}$-depletion cause an adaptive increase in transporter activity that persists when transporter activity is measured in vitro $(18,25)$. After citrate enters the cell, it can be transported into and metabolized by mitochondria in the tricarboxylic acid cycle (13). Simpson and Hager (32) have shown that decreases in extramitochondrial $\left[\mathrm{HCO}_{3}{ }^{-}\right]$acutely stimulate mitochondrial citrate uptake. However, it is not clear

Table II. Plasma Values for Animals Receiving Control, Acid, or $K^{+}$-free Diets Receiving Vehicle or the Competitive Inhibitor of ATP Citrate Lyase, $4 \mathrm{~S}$-hydroxycitrate (OH-citrate)

\begin{tabular}{|c|c|c|c|c|c|c|}
\hline & \multicolumn{2}{|c|}{ Control } & \multicolumn{2}{|c|}{ Acid } & \multicolumn{2}{|c|}{$\mathrm{K}^{+}$-depletion } \\
\hline & Vehicle & $\mathrm{OH}$-citrate & Vehicle & $\mathrm{OH}$-citrate & Vehicle & $\mathrm{OH}$-citrate \\
\hline $\mathrm{pH}$ & $7.47 \pm 0.01$ & $7.48 \pm 0.02$ & $7.45 \pm 0.01$ & $7.42 \pm 0.03$ & $7.49 \pm 0.01$ & $7.50 \pm 0.02$ \\
\hline $\mathrm{pCO}_{2}(\mathrm{mmHg})$ & $34.7 \pm 1.3$ & $31.3 \pm 1.2$ & $35.5 \pm 0.8$ & $35.3 \pm 2.2$ & $32.6 \pm 0.3$ & $32.3 \pm 1.0$ \\
\hline $\mathrm{HCO}_{3}(\mathrm{meq} / \mathrm{liter})$ & $25.2 \pm 0.3$ & $23.2 \pm 0.8$ & $25.2 \pm 0.6$ & $23.2 \pm 0.8$ & $24.9 \pm 0.3$ & $25.3 \pm 0.4$ \\
\hline $\mathrm{Na}$ (meq/liter) & $142 \pm 1$ & $144 \pm 1 *$ & $143 \pm 1$ & $144 \pm 1$ & $144 \pm 1$ & $141 \pm 1 *$ \\
\hline K (meq/liter) & $3.2 \pm 0.2$ & $3.2 \pm 0.1$ & $3.1 \pm 0.2$ & $2.9 \pm 0.1$ & $2.1 \pm 0.1$ & $2.1 \pm 0.1$ \\
\hline $\mathrm{Cl}$ (meq/liter) & $110 \pm 3$ & $111 \pm 2$ & $111 \pm 1$ & $113 \pm 1 *$ & $108 \pm 1$ & $105 \pm 1 *$ \\
\hline Creatinine $(\mathrm{mg} / \mathrm{dl})$ & $0.4 \pm 0.04$ & $0.4 \pm 0.04$ & $0.5 \pm 0.03$ & $0.5 \pm 0.02$ & $0.6 \pm 0.03$ & $0.7 \pm 0.03$ \\
\hline Glucose (mg/dl) & $188 \pm 7$ & $198 \pm 6$ & $186 \pm 6$ & $186 \pm 5$ & $187 \pm 11$ & $192 \pm 17$ \\
\hline Citrate (mg/liter) & $46 \pm 2$ & $41 \pm 4$ & $49 \pm 2$ & $39 \pm 2 *$ & $44 \pm 3$ & $39 \pm 3$ \\
\hline
\end{tabular}

$n=6$ for control and acid, $n=4$ for $\mathrm{K}^{+}$-depletion. $* P<0.05$ vs. vehicle group. 
whether in vivo changes in $\mathrm{pH}_{\mathrm{i}}$ and cytosolic $\left[\mathrm{HCO}_{3}{ }^{-}\right]$are sufficient to elicit this effect.

In other tissues, mitochondria produce and export citrate to the cytosol. In the cytosol, ATP citrate lyase catalyzes the conversion of citrate and $\mathrm{CoA}$ to oxaloacetate and acetyl CoA. The acetyl CoA is used in various acetylation processes and for the synthesis of fatty acids and cholesterol, while oxaloacetate enters the gluconeogenic pathway through phosphoenolpyruvate carboxykinase. In liver tissue, citrate is transported to the cytosol and cleaved by ATP citrate lyase for the production of fat (33), cholesterol (34), and glucose (35). Cytosolic citrate in the brain is catabolized by ATP citrate lyase for the formation of acetylcholine and myelin (36).

Kidney tissue homogenates possess the third highest activity of ATP citrate lyase, with brain and liver tissue having higher activities (24). Because of this high rate of activity, we hypothesized that this pathway could serve an important role in citrate metabolism in the proximal tubule. The most commonly used assay to assess ATP citrate lyase activity determines the formation of oxaloacetate by measuring consumption of NADH by malate dehydrogenase (21). However, when we attempted to employ this method, the magnitude of native renal NADH dehydrogenase activity interfered with that of malate dehydrogenase. We therefore turned to the hydroxamate assay. This assay measures the generation of acetylhydroxamate from acetyl CoA and hydroxylamine, and is useful in tissues with high intrinsic NADH dehydrogenase activity (21).

We found that chronic metabolic acidosis caused an increase in renal cortical ATP citrate lyase activity. However, this adaptation is tissue selective. Chronic metabolic acidosis did not affect hepatic ATP citrate lyase activity. This finding is similar to the effect of acidosis on phosphoenolpyruvate carboxykinase activity where it is also increased in the kidney and unaffected in liver (37).

Both chronic metabolic acidosis and $\mathrm{K}^{+}$-deficiency are associated with hypocitraturia (13). As these conditions have differential effects on extracellular $\mathrm{pH}$ but exhibit a similar decrease in $\mathrm{pH}_{\mathrm{i}}$, it has been inferred that the key determinant of hypocitraturia is intracellular acidosis (13). A similar increase in renal cortical ATP citrate lyase activity was elicited with chronic $\mathrm{K}^{+}$-deficiency as with chronic metabolic acidosis, again suggesting that decreases in $\mathrm{pH}_{\mathrm{i}}$ mediate this effect. In addition, converting enzyme inhibition, which may be expected to lower proximal tubular $\mathrm{pH}_{\mathrm{i}}(38)$, causes hypocitraturia and is also associated with an increase in ATP citrate lyase activity (39). These results demonstrate a strong correlation between hypocitraturia and increased ATP citrate lyase activity, suggesting that regulation of ATP citrate lyase activity may contribute to hypocitraturia.

To demonstrate this further, we examined the effect of the specific inhibitor of ATP citrate lyase, 4S-hydroxycitrate, on urinary citrate excretion. This compound increased urinary citrate excretion fourfold in acid-fed rats and threefold in $\mathrm{K}^{+}$depleted rats, significantly blunting the hypocitraturia in these two states. Together these studies suggest an important role for a proximal tubular cytoplasmic pathway involving ATP citrate lyase in citrate metabolism. In addition, the upregulation of this pathway plays an important role in hypocitraturia. The lack of complete reparation of the hypocitraturia by 4S-hydroxycitrate may be due to a lack of complete inhibition of the enzyme in vivo or may be due to the existence of other regulated pathways.
At least one component of the increase in renal cortical ATP citrate lyase activity associated with chronic metabolic acidosis is an increase in ATP citrate lyase protein abundance. In our studies, we found small but statistically insignificant changes in ATP citrate lyase mRNA abundance. These results are similar to those we found when we examined the effect of chronic metabolic acidosis on the brush border membrane $\mathrm{Na} / \mathrm{H}$ antiporter, $\mathrm{Na} / \mathrm{H}$ exchanger-3 (40). Chronic metabolic acidosis caused an increase in $\mathrm{Na} / \mathrm{H}$ antiporter activity and $\mathrm{Na} / \mathrm{H} \mathrm{ex}-$ changer-3 protein abundance, but no significant change in $\mathrm{Na} / \mathrm{H}$ exchanger-3 mRNA abundance. It is possible that while the increase in ATP citrate lyase mRNA after $3 \mathrm{~d}$ was not statistically significant, this change in mRNA is sufficient to lead to cumulative changes in ATP citrate lyase protein synthesis and abundance. Alternatively, the results suggest that metabolic acidosis may have a direct effect on ATP citrate lyase protein synthesis or degradation.

Chronic metabolic acidosis causes an increase in proximal tubular apical membrane uptake and metabolism of citrate. The present study shows that chronic metabolic acidosis increases the activity and protein abundance of renal cortical ATP citrate lyase and that upregulation of this enzyme plays an important role in the generation of hypocitraturia. ATP citrate lyase metabolizes citrate to oxaloacetate and acetyl CoA. The oxaloacetate generated is metabolized through phosphoenolpyruvate carboxykinase, the activity of which is also increased in chronic metabolic acidosis (37). Overactivity of ATP citrate lyase may provide an etiology for hypocitraturia, and inhibition of this enzyme may provide a target for treatment of hypocitraturia.

\section{Acknowledgments}

The authors gratefully acknowledge the advice and support of Charles Pak and Khashayar Sakhaee, and technical help and advice from Patrice Ambühl, Paulette Padalino, and Ebtisam Abdul-Salam.

These studies were supported by National Institutes of Health (NIH) grant P01-DK20543. J.Z. Melnick was supported by NIH grant T32-DK07659. 4S-hydroxycitrate was generously provided by Hoffman-LaRoche, Nutley, NJ.

\section{References}

1. Pak, C.Y.C. 1987. Citrate and renal calculi. Miner. Electrolyte Metab. 13: 257-266.

2. Hess, B., L. Zipperle, and P. Jaeger. 1994. Citrate and calcium effects on Tamm-Horsfall glycoprotein as a modifier of calcium oxalate crystal aggregation. Am. J. Physiol. 265:F784-F791.

3. Nicar, M.J., C. Skurla, K. Sakhaee, and C.Y.C. Pak. 1983. Low urinary citrate excretion in nephrolithiasis. Urology. 21:8-14.

4. Preminger, G.M., K. Sakhaee, C. Skurla, and C.Y.C. Pak. 1985. Prevention of recurrent calcium stone formation with potassium citrate therapy in patients with distal renal tubular acidosis. J. Urol. 134:20-23.

5. Rudman, D., J.L. Dedonis, M.T. Fountain, J.B. Chandler, G.G. Gerron, G.A. Fleming, and M.H. Kutner. 1980. Hypocitraturia in patients with gastrointestinal malabsorption. N. Engl. J. Med. 303:657-661.

6. Sakhaee, K., S. Nigam, P. Snell, M.C. Hsu, and C.Y.C. Pak. 1987. Assessment of the pathogenetic role of physical exercise in renal stone formation. $J$. Clin. Endocrinol. Metab. 65:974-979.

7. Breslau, N.A., L. Brinkley, K.D. Hill, and C.Y.C. Pak. 1988. Relationship of animal protein-rich diet to kidney stone formation and calcium metabolism. J. Clin. Endocrinol. Metab. 66:140-146.

8. Ottley, C.M. 1953. Diminished urinary excretion of citrate during deficiencies of potassium in man. Lancet. ii:656-657.

9. Adam, W.R., A.P. Koretsky, and M.W. Weiner. 1986. ${ }^{31} \mathrm{P}-\mathrm{NMR}$ in vivo measurement of renal intracellular $\mathrm{pH}$ : effects of acidosis and $\mathrm{K}^{+}$depletion in rats. Am. J. Physiol. 251:F904-F910.

10. Hamm, L.L. 1990. Renal handling of citrate. Kidney Int. 38:728-735.

11. Kippen, I., B. Hirayama, J.R. Klinenberg, and E.M. Wright. 1979. 
Transport of tricarboxylic acid cycle intermediates by membrane vesicles from renal brush border. Proc. Natl. Acad. Sci. USA. 76:3397-3400.

12. Pajor, A.M. 1995. Sequence and functional characterization of a renal sodium/dicarboxylate cotransporter. J. Biol. Chem. 270:5779-5785.

13. Simpson, D.P. 1983. Citrate excretion: a window on renal metabolism. Am. J. Physiol. 244:F223-F234.

14. Srere, P.A. 1982. The molecular physiology of citrate. Curr. Top. Cell. Regul. 33:261-275.

15. Sullivan, A.C., M. Singh, P.A. Srere, and J.P. Glusker. 1977. Reactivity and inhibitor potential of hydroxycitrate isomers with citrate synthase, citrate lyase, and ATP citrate lyase. J. Biol. Chem. 252:7583-7590.

16. Nicar, M.J., M.C. Hsu, T. Johnson, and C.Y.C. Pak. 1987. The preservation of urine samples for determination of renal stone risk factors. Clin. Chem. 18:382-384.

17. Lowenstein, J.M. 1971. Effect of (-)-hydroxycitrate on fatty acid synthesis by rat liver in vivo. J. Biol. Chem. 246:629-632.

18. Levi, M., L.A. McDonald, P.A. Preisig, and R.J. Alpern. 1991. Chronic $\mathrm{K}$ depletion stimulates rat renal brush-border membrane Na-citrate cotransporter. Am. J. Physiol. 261:F767-F773.

19. Cottam, G.L., and P.A. Srere. 1969. The sulfhydryl groups of citrate cleavage enzyme. Arch. Biochem. Biophys. 130:304-311.

20. Lipmann, F., and L.C. Tuttle. 1945. A specific micromethod for the determination of acyl phosphates. J. Biol. Chem. 159: 21-28.

21. Takeda, Y., F. Suzuki, and H. Inoue. 1969. ATP citrate lyase. Methods Enzymol. 13:153-160.

22. Elshourbagy, N.A., J.C. Near, P.J. Kmetz, G.M. Sathe, C. Southan, J.E. Strickler, M. Gross, J.F. Young, T.N.C. Wells, and P.H.E. Groot. 1990. Rat ATP citrate-lyase. J. Biol. Chem. 265:1430-1435.

23. Moe, O.W., R.T. Miller, S. Horie, A. Cano, P. Presig, and R.J. Alpern. 1991. Differential regulation of $\mathrm{Na} / \mathrm{H}$ antiporter by acid in renal epithelial cells and fibroblasts. J. Clin. Invest. 88:1703-1708.

24. Srere, P.A. 1959. The citrate cleavage enzyme. J. Biol. Chem. 234:25442547.

25. Jenkins, A.D., T.P. Dousa, and L.H. Smith. 1985. Transport of citrate across renal brush border membrane: effects of dietary acid and alkali loading. Am. J. Physiol. 249:F590-F595.

26. Singh, M., E.G. Richards, A. Mukherjee, and P.A. Srere. 1976. Structure of ATP citrate lyase from rat liver. J. Biol. Chem. 251:5242-5250.

27. Adler, S., B. Zett, and B. Anderson. 1974. Renal citrate in the potas- sium-deficient rat: role of potassium and chloride ions. J. Lab. Clin. Med. 84: 307-316.

28. Simpson, D.P. 1983. Mitochondrial transport functions and renal metabolism. Kidney Int. 23:785-793.

29. Hernandez, R.E., M. Schambelan, M.G. Cogan, J. Colman, R.C. Morris, Jr., and A. Sebastian. 1987. Dietary $\mathrm{NaCl}$ determines severity of potassium depletion-induced metabolic alkalosis. Kidney Int. 31:1356-1367.

30. Cheema-Dhadli, S., M.L. Halperin, and C.C. Leznoff. 1973. Inhibition of enzymes which interact with citrate by $(-)$ hydroxycitrate and 1,2,3,-tricarboxybenzene. Eur. J. Biochem. 38:98-102.

31. Wright, S.H., I. Kippen, and E.M. Wright. 1982. Effect of $\mathrm{pH}$ on the transport of Krebs cycle intermediates in renal brush border membranes. Biochim. Biophys. Acta. 684:287-290.

32. Simpson, D.P., and S.R. Hager. 1979. $\mathrm{pH}$ and bicarbonate effects on mitochondrial anion accumulation. J. Clin. Invest. 63:704-712.

33. Numa, S., and S. Yamashita. 1974. Regulation of lipogenesis in animal tissues. Curr. Top. Cell. Regul. 8:197-246.

34. Parlo, R.A., and P.S. Coleman. 1984. Enhanced rate of citrate export from cholesterol-rich hepatoma mitochondria. J. Biol. Chem. 259:9997-10003.

35. Des Rosiers, C., L. Di Donato, B. Comte, A. Laplante, C. Marcoux, F.

David, C.A. Fernandez, and H. Brunengraber. 1995. Isotopomer analysis of citric acid cycle and gluconeogenesis in rat liver. J. Biol. Chem. 270:10027-10036.

36. Szutowicz, A., J. Kabata, and H. Bielarczyk. 1982. The contribution of citrate to the synthesis of acetyl units in synaptosomes of developing rat brain J. Neurochem. 38:1196-1204.

37. Alleyne, G.A.O., and G.H. Scullard. 1969. Renal metabolic response to acid base changes I. Enzymatic control of ammoniagenesis in the rat. J. Clin. Invest. $48: 364-370$.

38. Geibel, J., G. Giebisch, and W.F. Boron. 1990. Angiotensin II stimulates both $\mathrm{Na}+-\mathrm{H}+$ exchange and $\mathrm{Na}+/ \mathrm{HCO} 3$-cotransport in the rabbit proximal tubule. Proc. Natl. Acad. Sci. USA. 87:7917-7920.

39. Melnick, J.Z., P.A. Srere, P.A. Preisig, and R.J. Alpern. 1995. Hypocitraturia of chronic metabolic acidosis, hypokalemia \& angiotensin converting enzyme inhibition is mediated by an adaptation in renal cortical ATP citrate lyase activity. Pediatr. Res. 33:366a. (Abstr.)

40. Ambühl, P.M., M. Amemiya, M. Lotscher, M. Danczkay, B. Kaissling, O.W. Moe, P.A. Preisig, and R.J. Alpern. 1996. Chronic metabolic acidosis increases NHE-3 protein abundance in rats. Am. J. Physiol. 271: F917-F925. 